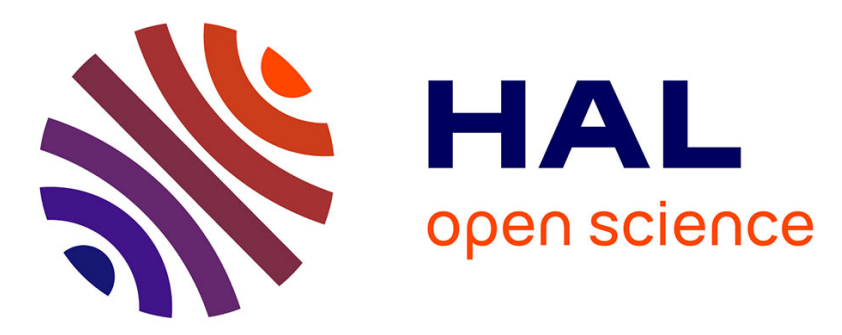

\title{
Unprecedented Nucleophilic Attack of Piperidine on the Electron Acceptor during the Synthesis of Push-Pull Dyes by a Knoevenagel Reaction
}

Corentin Pigot, Guillaume Noirbent, Sebastien Peralta, Sylvain Duval, Malek Nechab, Didier Gigmes, Frederic Dumur

\section{To cite this version:}

Corentin Pigot, Guillaume Noirbent, Sebastien Peralta, Sylvain Duval, Malek Nechab, et al.. Unprecedented Nucleophilic Attack of Piperidine on the Electron Acceptor during the Synthesis of Push-Pull Dyes by a Knoevenagel Reaction. Helvetica Chimica Acta, 2019, 10.1002/hlca.201900229 . hal02491522

\section{HAL Id: hal-02491522 \\ https://hal.science/hal-02491522}

Submitted on 8 Jul 2020

HAL is a multi-disciplinary open access archive for the deposit and dissemination of scientific research documents, whether they are published or not. The documents may come from teaching and research institutions in France or abroad, or from public or private research centers.
L'archive ouverte pluridisciplinaire HAL, est destinée au dépôt et à la diffusion de documents scientifiques de niveau recherche, publiés ou non, émanant des établissements d'enseignement et de recherche français ou étrangers, des laboratoires publics ou privés. 


\section{Helvetica Chimica Acta}

\section{Unprecedented Nucleophilic Attack of Piperidine on the Electron Acceptor during the Synthesis of Push-Pull Dyes by a Knoevenagel Reaction \\ --Manuscript Draft--}

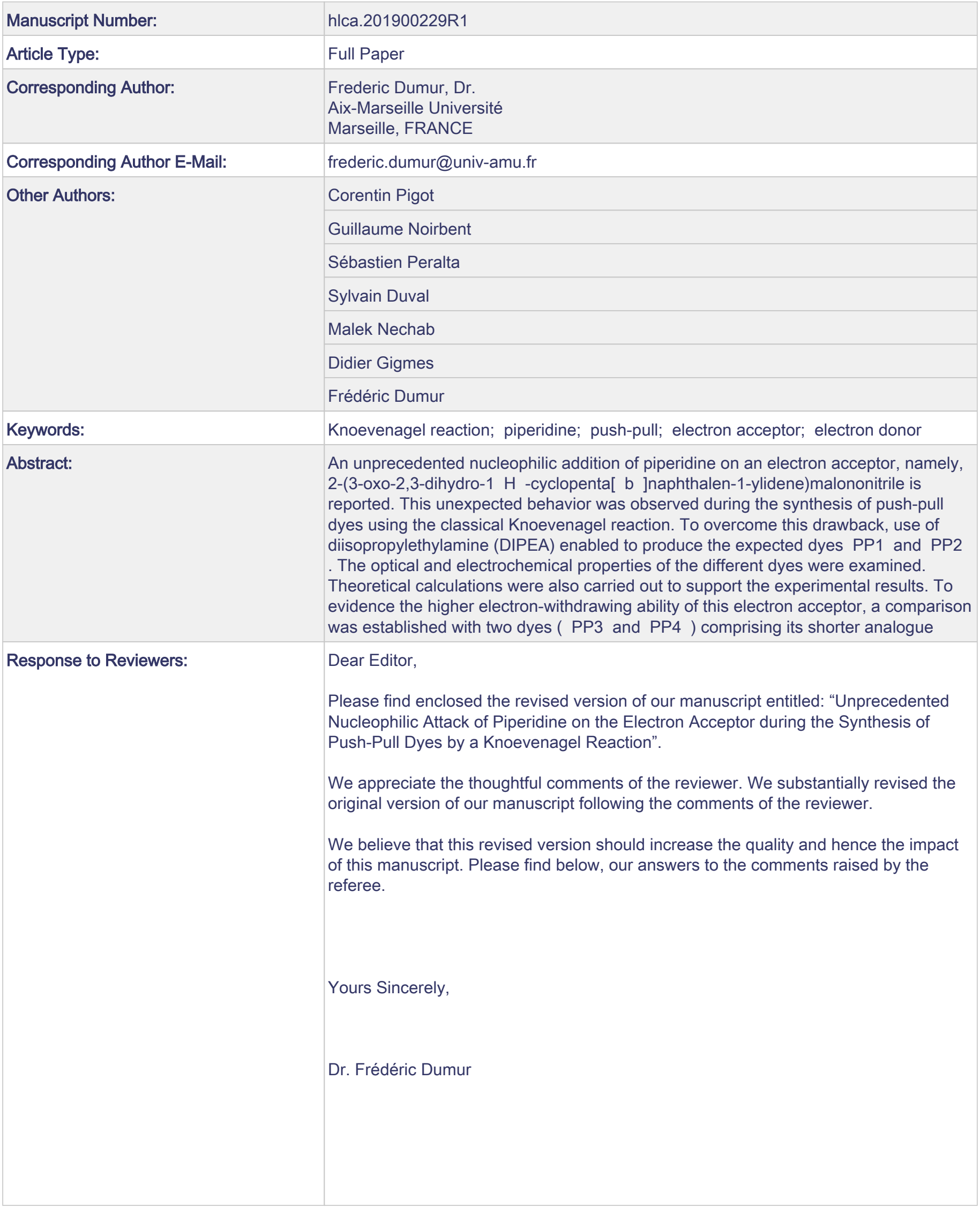


References:

Please provide the title for the article of each reference in 'simple quotation marks'.

Titles of all articles have been added.

Composite references should be avoided. For each reference, a single number should be used. Please renumber the references.

All references have been separated.

CCDC Number:

Please provide the missing CCDC numbers at appropriate place.

The CCDC number has been added.

Graphical Abstract: A representative structural formula, scheme, or figure should be provided for the Table of Contents. The maximum available space for this graphical abstract is $7 \times 11 \mathrm{~cm}$.

The graphical abstract has been modified.

Graphical Material: For each Figure or Scheme containing any chemical structures or formulae, please provide a separate ChemDraw file (One file per Formulae collection, Figure, or Scheme). Additionally, please provide the separate graphic files for all figures. Please adjust the dimensions of the graphics to either one- or two-column representation. For one-column figures, the width is max. $8.1 \mathrm{~cm}$, with $600 \mathrm{dpi}$ resolution, for two column graphics max. $17.0 \mathrm{~cm}$ width, with $600 \mathrm{dpi}$ resolution. Graphical files with lower resolution will lead to poor quality. If you cannot provide Tiffiles, please provide the original files.

Files of the original graphics/artwork in easy-to-handle formats like ChemDraw, TIF or EPS or, alternatively, PDF files generated from all your vector graphics are highly welcome for print purposes.

Separated files are provided for all schemes and figures.

Reviewer \#1:

Dumur et al described not only the addition of piperidine on electron acceptors giving the corresponding enamine, an improved synthesis of cyclopentanaphtaleylidenemalonitrile and the synthesis of push-pull dyes based on cyclopentanaphtalylidenemalonitrile. The optoelectronic properties were compared with its smaller homologue as (dicyanomethylidene)indan-1-one.

The manuscript deserves publications, but some points have to be clarified.

1) In the following sentence, the word "aromaticity" should be changed to "core". "It has to be noticed that only few materials have been designed with Napht-EA, despites its extended aromaticity that makes it an ideal electron-withdrawing candidate for the design of materials for photovoltaic applications".

"Aromaticity" has been changed to "core". 
2) The scheme 3 related to the formation of PP6 should be removed since the reaction is a simple enamine formation.

Scheme 3 has been removed as suggested. Considering that the scheme was commented in the text, the corresponding paragraph has been removed.

3) In section 3, the authors indicate that the LUMO is mainly centered on the electron acceptor. Looking at the LUMO orbitals, it appears that the LUMO is delocalized over the whole molecule. This should be changed in the main text.

The paragraph has been modified as suggested.

4) In table 2, the experimental HOMO-LUMO gaps have been determined by UV/Vis spectroscopy or cyclovoltammetry? In any case, the value seems to be wrong. Let's take PP1 as example. The HOMO-LUMO gap written is table 1 is $2.13 \mathrm{eV}$. In the UV/Visible spectrum, the lambda onset is around $640 \mathrm{~nm}$ that correspond to a band gap of $1.94 \mathrm{eV}$. By cyclovoltammetry, $\mathrm{HOMO}$ is at $-5.36 \mathrm{eV}$ and LUMO is at $-3.61 \mathrm{eV}$ consequently the HOMO-LUMO gap is of $-3.61+5.36=1.75 \mathrm{eV}$. The authors should clarify that in table 1.

In fact, all optical HOMO-LUMO gaps have been determined by using the absorption maximum and not the onset of the intramolecular charge transfer band. Values in the Table 1 have been modified as suggested by the reviewer.

Concerning the HOMO-LUMO gap determined by cyclic voltammetry, an additional column has been introduced in the Table 1. These values are consistent with those determined from the UV-visible absorption spectra. IN fact, a difference of $0.2 \mathrm{eV}$ can be determined between the electrochemical and optical bandgap. This difference increases to $0.4 \mathrm{eV}$ with the theoretical ones. The text has been corrected accordingly.

5) In section 4, "At similar electron acceptor, reduction of PP2 was shifted at more cathodic potentials by ca. $200 \mathrm{mV}$ compared to PP1. Thus, the irreversible reduction of PP2 was observed at $-1.18 \mathrm{~V}$ contrarily to $-0.98 \mathrm{~V}$ for PP1". ... As a result of this, Napht-EA is less acceptor in PP2 than in PP1 due to the electron donating effect of the extended donor. Cathodic shift of the reduction potential with elongation of the $\pi-$ conjugated length was previously reported in the literature...

According to the table 4, PP2 is reduced at $-1.07 \mathrm{~V}$ and PP1 at $-1.19 \mathrm{~V}$. Consequently, the insertion of an additional double bond between the $A$ and $D$ moieties leads to $a$ shift of the reduction potential of $0.120 \mathrm{~V}$ to more cathodic potentials. Consequently, PP2 get reduced more easily than PP1 and therefor PP2 is a better acceptor than PP1. Actually, the authors find an opposite trend than in ref16. All the paragraph mentioned should be rewritten.

We thank the reviewer for its comments. Indeed, in the present case, elongation of the conjugated spacer facilitates the reduction of the acceptor, what is the opposite trend classically reported in the literature. This is due to the fact that for these compounds, the LUMO extends over the whole molecule, including the electron donor. Consequently, when a spacer is introduced, the negative effect of the electron donor affects less the electron acceptor due to the distance between the two partners. As a result of this, the reduction is facilitated. The paragraph has been totally rewritten.

6) The NMR spectra are missing in the supporting info.

NMR spectra have been included.

Additional Information:

Question

Response

Submitted solely to this journal? Yes

Has there been a previous version? No

Dedication

The corresponding author(s) and co-

No / Don't know

author(s) have the option of making their 
article open access through our OnlineOpen service (fee applicable).

Please indicate here if you are likely to

publish your article in an open-access

format. 


\title{
Unprecedented Nucleophilic Attack of Piperidine on the Electron Acceptor during the Synthesis of Push-Pull Dyes by a Knoevenagel Reaction
}

\author{
Corentin Pigot, ${ }^{*}$ a Guillaume Noirbent, ${ }^{a}$ Sébastien Peraltab ${ }^{b}$, Sylvain Duval, ${ }^{c}$ Malek Nechab, ${ }^{a}$ Didier Gigmes ${ }^{a}$ \\ and Frédéric Dumur ${ }^{\star a}$ \\ a Aix Marseille Univ, CNRS, ICR UMR 7273, F-13397 Marseille, France, corentin.pigot@univ-amu.fr, frederic.dumur@univ-amu.fr
}

b Laboratoire de Physicochimie des Polymères et des Interfaces (LPPI), Université de Cergy Pontoise, 5 mail Gay Lussac, F-95000 Neuville-sur-

Oise, France

c Université de Lille, CNRS, Centrale Lille, ENSCL, Univ. Artois, UMR 8181 - UCCS - Unité de Catalyse et Chimie du Solide, F-59000 Lille, France

An unprecedented nucleophilic addition of piperidine on an electron acceptor, namely, 2-(3-oxo-2,3-dihydro-1H-cyclopenta[b]naphthalen-1ylidene)malononitrile is reported. This unexpected behavior was observed during the synthesis of push-pull dyes using the classical Knoevenagel reaction. To overcome this drawback, use of diisopropylethylamine (DIPEA) enabled to produce the expected dyes PP1 and PP2. The optical and electrochemical properties of the different dyes were examined. Theoretical calculations were also carried out to support the experimental results. To evidence the higher electron-withdrawing ability of this electron acceptor, a comparison was established with two dyes (PP3 and PP4) comprising its shorter analogue.

Keywords: Knoevenagel reaction $\bullet$ piperidine $\bullet$ push-pull $\bullet$ electron acceptor $\bullet$ electron donor

\section{Introduction}

During the past decades, push-pull dyes have been extensively studied with regards to their numerous applications ranging from sensors, [1,2] energy conversion, $[3,4]$ field effects transistors, [5,6] organic light-emitting diodes, $[7,8]$ nonlinear optics $[9,10]$ or photoinitiators of polymerization.[11-15] To access to these structures consisting in an electron donor connected to an electron acceptor by mean of a conjugated or none-conjugated spacer, the Knoevenagel reaction is undoubtedly the most popular reaction, opposing an aldehyde with an electron acceptor bearing an activated methylene group, in the presence of a catalytic amount of a base. Popularity of this reaction also arises from the facile availability of electron acceptors possessing activated methylene groups and malononitrile, indane-1,3-dione derivatives, (thio)barbituric derivatives, Meldrum derivatives, 1,1,3-tricyano-2-substituted propenes, isoxazolones, hydantions and rhodanines, and dicyanovinyl-thiophen-5-ylidenes can be cited as the most widely studied. $[16,17]$ Interest for this reaction also originates from the easy work-up following the synthesis of the dyes. Indeed, the reaction is classically done by refluxing the reagents in ethanol and use of alcohols as solvents favors the precipitation of the dyes upon cooling. As a result, the expected products can be generally recovered in pure form by a simple filtration on a glass filtrate.
Among amines, piperidine is the most widely used.[18,19] In this field, the first condensation of benzaldehyde with ethyl acetoacetate in the presence of piperidine was reported as soon as 1896 by Knoevenagel providing the product in $95 \%$ yield.[20] In this work, an unprecedented nucleophilic attack of piperidine during a Knoevenagel reaction with 2-(3-oxo-2,3-dihydro-1Hcyclopenta[b] naphthalen-1-ylidene)malononitrile Napht-EA was evidenced (See Figure 1). It has to be noticed that only few materials have been designed with Napht-EA, despites its extended core that makes it an ideal electron-withdrawing candidate for the design of materials for photovoltaic applications. In this field, the preliminary results revealed Napht-EA to be promising as a non-fullerene electron acceptor for the design of push-pull materials for energy conversion, justifying the development of new structures.[21-23] The low availability of Napht-EA-based push-pull dyes also originates from the difficult access to Napht-EA so that a careful optimization of the reaction conditions was required to prepare the different dyes. After optimization, Napht-EA could be prepared with reaction yield as high as $91 \%$ yield. To avoid the nucleophilic attack on Naphth-EA a non-nucleophilic base i.e. diisopropylethylamine (DIPEA) was used and the two targeted push-pull dyes PP1 and PP2 could be finally obtained in high yields. To evidence the benefits of the polyaromatic nature of Napht-EA, push-pull analogues PP3 and PP4 based on indane-1,2-dione derivatives were designed and synthesized for 
comparison (See Figure 1). The optical and electrochemical properties of the different dyes were examined. To support the experimental results, theoretical calculations were carried out.

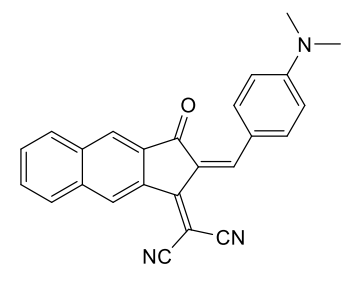

PP1

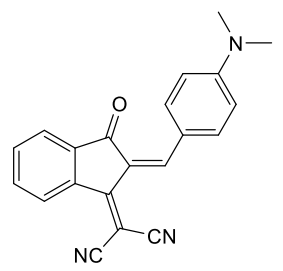

PP3
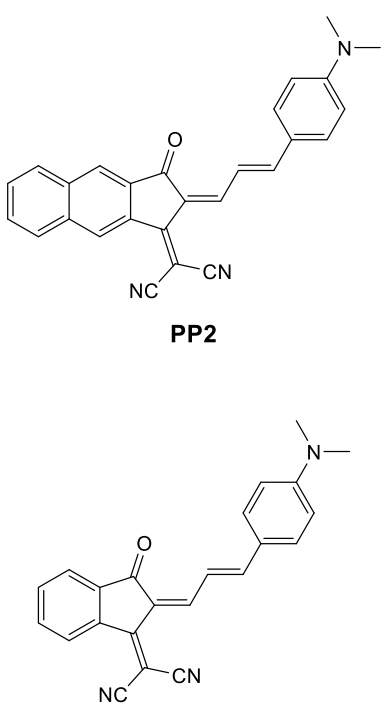

PP4<smiles>N#CC(C#N)=C1CC(=O)c2cc3ccccc3cc21</smiles>

Napht-EA
Figure 1. Chemical structures of PP1-PP4 and the electron acceptor Napht-

EA.

\section{Results and Discussion}

\section{1- Synthesis of Napht-EA.}

The precursor of Napht-EA i.e. $1 H$-cyclopenta[b]naphthalene$1,3(2 H)$-dione was synthesized by introducing several modifications to the procedure previously reported in the literature, in 1973.[24] Typically, $1 H$-cyclopenta[b]naphthalene-1,3(2H)-dione can be prepared in a two-steps synthesis, by decarboxylation of the intermediate sodium salt under acidic conditions, this intermediate being obtained by a Claisen condensation of ethyl acetate with diethyl naphthalene-2,3-dicarboxylate (See Scheme 1). As the first improvement, an increased amount of sodium hydride was used for the first step ( 2.5 eq. vs. 1.45 eq. in the literature), this reaction being carried out without solvents. Indeed, the reagent i.e. ethyl acetate also acts as the solvent and this latter was introduced in a sufficient quantity $(0.6 \mathrm{~mL} / \mathrm{mmole})$ to suspend diethyl naphthalene-2,3dicarboxylate, producing rapidly a sticky paste upon heating. By increasing the volume of ethyl acetate, a dramatic reduction of the reaction yield was observed.
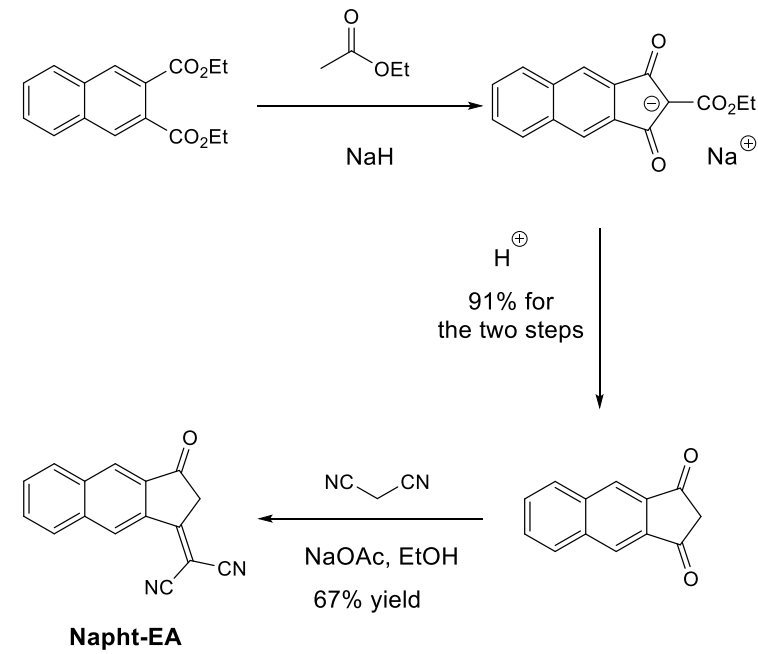

Scheme 1. Synthetic scheme of Napht-EA.

Second, by increasing the decarboxylation time from 20 min. to 90 min., the reaction yield could be improved up to $91 \%$ for the two steps, significantly higher than that previously reported in the literature (65\% yield). By condensation of malononitrile on $1 \mathrm{H}$ cyclopenta[b]naphthalene-1,3(2H)-dione under basic conditions,

Napht-EA could be obtained in $67 \%$ yield.

\section{2- Synthesis of PP1-PP4}

As already mentioned, the first attempts to prepare PP1 and PP2 consisted in refluxing for $30 \mathrm{~min}$. an equimolar amount of 4dimethylamino-benzaldehyde or 3-(4-(dimethylamino)phenyl) acrylaldehyde with Napht-EA in the presence of piperidine. Surprisingly, in the two cases, none of the expected dyes PP1 or PP2 were obtained (See Scheme 2). In the first case, a red solid PP5 was formed, corresponding to the nucleophilic addition of piperidine onto PP1 followed by a cyclization reaction. PP5 was isolated after purification in $14 \%$ yield. The formation of 3-(dialkylamino)-1,2dihydro-9-oxo-9H-indeno[2,1-c]pyridine-4-carbonitrile derivatives has been previously reported in the literature by Landmesser et al. on 3-(dicyanomethylidene)indan-1-one, using the same reaction conditions.[25] Conversely, while opposing 3-(4-(dimethylamino) phenyl)acrylaldehyde to Napht-EA, an unexpected product was formed (PP6) whose structure was determined by proton nuclear magnetic resonance $\left({ }^{1} \mathrm{H}\right.$ NMR). As shown in the Figure 2 , no presence of the dimethylaminophenyl group was found in the ${ }^{1} \mathrm{H}$ NMR spectrum of PP6. On the opposite, two sets of signals at 1.85 and 3.86 ppm corresponding to a piperidine adduct and a singlet at 5.87 
ppm integrating for one proton were detected. The exact chemical structure of PP6 could be determined by X-Ray diffraction (XRD) analyses done on single crystals grown by slow evaporation of chloroform. As evidenced in the Figure 3, an addition of piperidine onto the Napht-EA scaffold could be clearly evidenced.

Face to these considerations and to avoid the addition of piperidine on PP1 (resulting in the formation of PP5) or on Napht-EA

(producing PP6), a non-nucleophilic base was used. Using DIPEA,

PP1 and PP2 could be isolated in 68 and 44\% yield respectively. For further comparison of the photophysical properties of PP1 and PP2

PP3 and PP4 were synthesized starting from 3-(dicyanomethylidene) indan-1-one as the electron acceptor and isolated in pure form with reaction yields of 55 and $45 \%$ respectively (See Scheme 3).
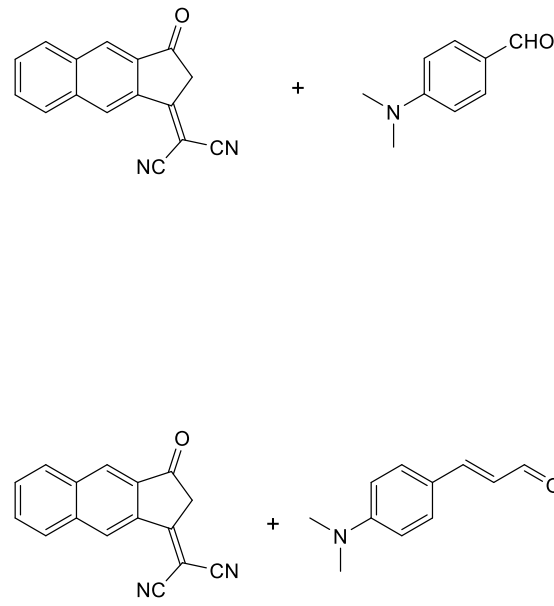

\section{3- UV-visible absorption and photoluminescence spectroscopy}

The optical properties of the different dyes reported in this work were examined in chloroform. Due to the reduced solubility of PP1 and PP2 in most of the common organic solvents, no investigation of the solvatochromic properties could be carried out. Besides, a series of conclusions can nevertheless be established. A summary of the main absorption characteristics is provided in the Table 1. As evidenced in the Figure $4 a$, all dyes displayed a main transition centered in the visible range corresponding to the intramolecular charge transfer band (ICT) of the chromophore. A significant red-shift of the ICT bands upon elongation of the conjugated spacer between the electron donating and the electron-accepting groups could be demonstrated with PP2 and PP4 compared to PP1 and PP3 respectively.

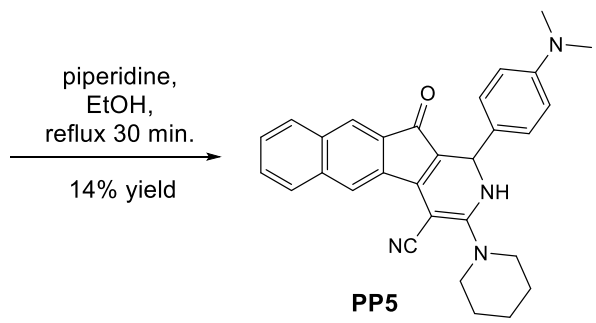

PP5

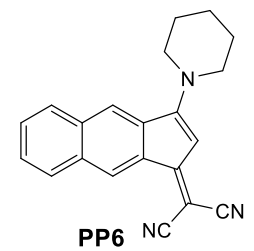

Scheme 2. Synthetic scheme of PP5 and PP6.

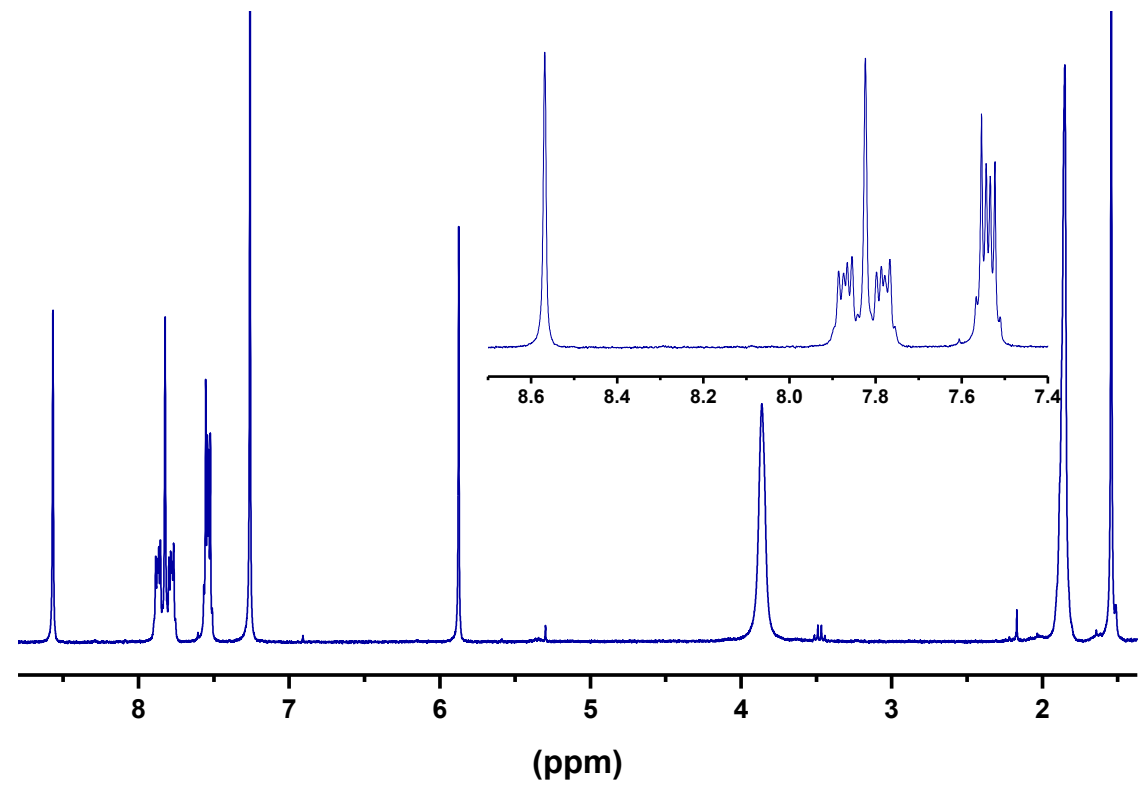

Figure 2. ${ }^{1} \mathrm{H}$ NMR spectrum of $\mathbf{P P 6}$ in $\mathrm{CDCl}_{3}$ (7.26 ppm) (left). 


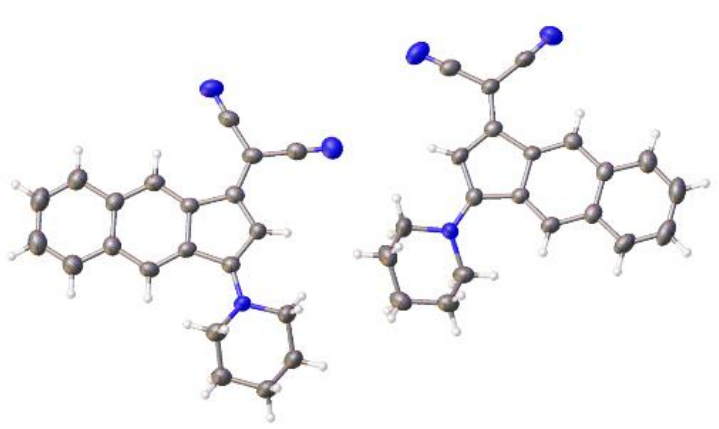

Figure 3. X-ray crystal structure of PP6<smiles>CN(C)c1ccc(C=C2C(=O)c3cc4ccccc4cc3C2=C(C#N)C#N)cc1</smiles>

PP1

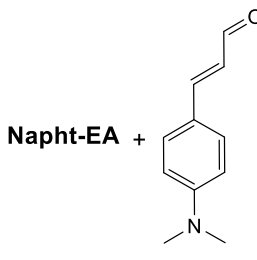
DIPEA, EtOH,
reflux $30 \mathrm{~min}$. $44 \%$ yield<smiles>CCc1ccccc1C</smiles><smiles>C=C1C(=CC)C(=C(C#N)C#N)c2cc(C)ccc21</smiles>

PP2<smiles>CN(C)c1ccc(C=C2C(=O)c3ccccc3C2=C(C#N)C#N)cc1</smiles>

PP3<smiles></smiles><smiles></smiles>

PP4

Scheme 3. Synthetic route to PP1-PP4.

Notably, a red-shift as high as $80 \mathrm{~nm}$ for PP2 and $70 \mathrm{~nm}$ for PP4 could be found, relative to PP1 and PP3 respectively. This is consistent with an improvement of the electron-donating ability of the electron donors by extending the $\pi$-conjugation.[26]

As evidenced in the Figure 5, the highest occupied molecular orbital (HOMO) comprises both the dimethylaminobenzene group as well as the conjugated spacer. Conversely, the lowest unoccupied molecular orbital (LUMO) extends over the whole molecule. As a result of this, a destabilization of the HOMO energy levels is observed in PP2 and

PP4. Parallel to this, an improvement of the molar extinction coefficient with the conjugation extension and therefore the oscillator strength was also demonstrated (See Table 1).[27] While comparing the dyes at constant electron donors, a red-shift of $30 \mathrm{~nm}$ was found for all dyes prepared with Napht-EA (PP1 vs. PP3, PP2 vs. PP4), consistent with an improved electron-withdrawing ability of Napht-EA relative to 3-(dicyanomethylidene)indan-1-one. Comparison of the theoretical UV-visible absorption spectra with the experimental ones revealed the order of the dyes to be the same even if a blue-shift by about $100 \mathrm{~nm}$ was found for all theoretical spectra relative to the experimental ones.

a)

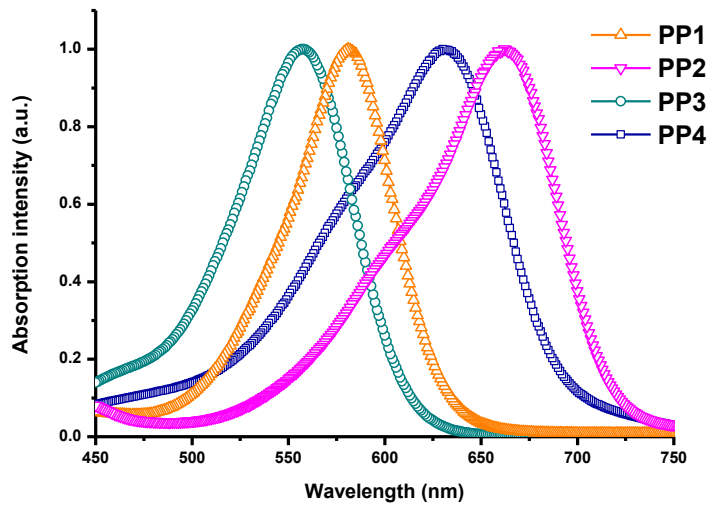

b)

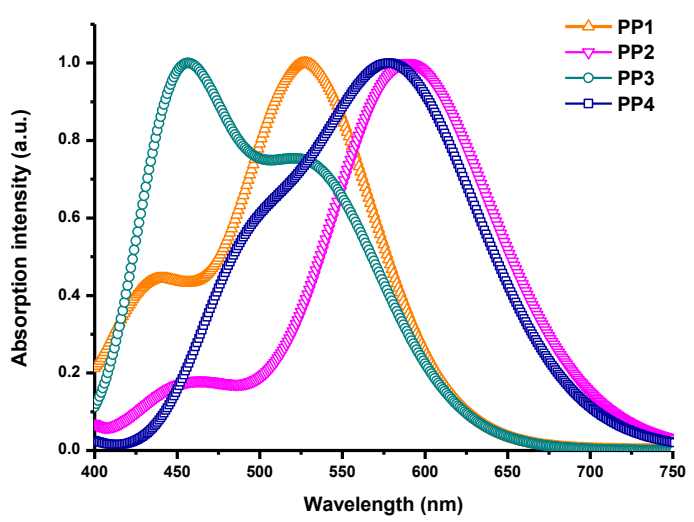

Figure 4. Experimental (a) and theoretical (b) UV-visible absorption spectra of PP1-PP4. Experimental spectra were recorded in chloroform.

This is attributable that the solvent effect which is incorrectly considered during the calculations. A summary of the main transitions involved in the ICT bands is provided in the table 2. As classical observed for push-pull dyes, the ICT bands of PP1-PP4 mostly arise from a HOMO-> LUMO transition, even if a nonenegligible contribution of the HOMO->LUMO+1 transition is also found for PP3. Finally, comparison of the theoretical and experimental HOMO-LUMO gaps showed a good agreement (See Table 2). 


\section{HELVETICA}

Table 1. UV-visible absorption characteristics of the different dyes in chloroform $\left(\mathrm{C}=5 \times 10^{-3} \mathrm{M}\right)$

\begin{tabular}{ccccccc}
\hline dyes & PP1 & PP2 & PP3 & PP4 & PP5 & PP6 \\
\hline $\boldsymbol{\lambda}_{\mathbf{1}}{ }^{a}$ & 310 & 330 & 367 & 304 & 323 & 332 \\
& $(16300)$ & $(12350)$ & $(4900)$ & $(17100)$ & $(25400)$ & $(16500)$ \\
$\boldsymbol{\lambda}_{\mathbf{2}}$ & 330 & $351(\mathrm{sh})$ & 559 & 630 & 333 & 345 \\
& $(14500)$ & $(7400)$ & $(28150)$ & $(37500)$ & $(26700)$ & $(18050)$ \\
$\boldsymbol{\lambda}_{\mathbf{3}}$ & 395 & 421 & & & 366 & 363 \\
& $(6300)$ & $(3450)$ & & & $(4300)$ & $(13100)$ \\
$\boldsymbol{\lambda}_{\mathbf{4}}$ & $421(\mathrm{sh})$ & 663 & & & 388 & 396 \\
& $(5200)$ & $(23200)$ & & & $(5700)$ & $(7600)$ \\
$\boldsymbol{\lambda}_{\mathbf{5}}$ & 580 & & & & 415 & 422 \\
& $(33350)$ & & & & $(6100)$ & $(9150)$ \\
$\boldsymbol{\lambda}_{\mathbf{6}}$ & & & & & $(3950)$ & $(13650)$ \\
& & & & & & 502 \\
$\boldsymbol{\lambda}_{\mathbf{7}}$ & & & & & & $(17400)$ \\
$\boldsymbol{\lambda}_{\mathbf{8}}$ & & & & & & \\
& & & & & & \\
\end{tabular}

${ }^{a}$ Wavelength are given in $\mathrm{nm}$. Values in brackets correspond to the molar extinction coefficients at the corresponding wavelength.

\section{Compounds}

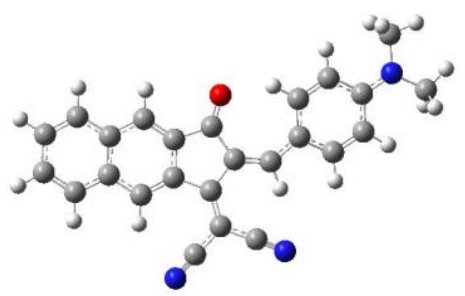

PP1
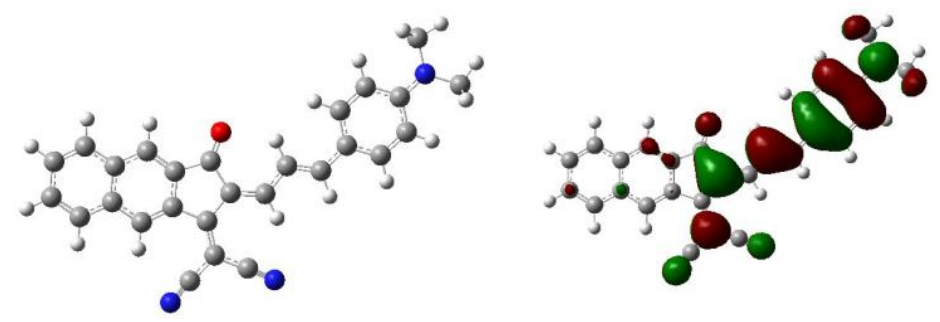

PP2
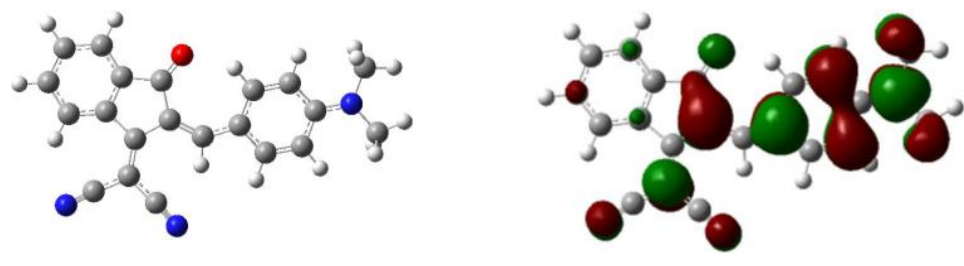

PP3

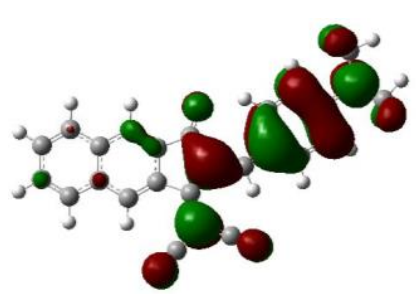

LUMO

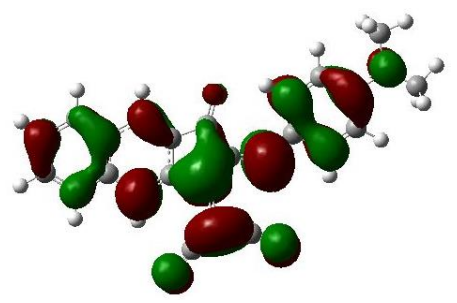

\begin{tabular}{|c|c|c|c|c|c|c|c|}
\hline dyes & $\begin{array}{c}\text { Еномо }_{\text {но }} \\
(\mathrm{eV})\end{array}$ & $\begin{array}{c}\mathbf{E}_{\text {номо }} \\
(\mathrm{eV})\end{array}$ & $\begin{array}{l}\lambda_{\max } \\
(\mathbf{n m})\end{array}$ & $\begin{array}{l}\Delta \mathrm{E}_{\mathrm{th}} \\
(\mathrm{eV})\end{array}$ & $\begin{array}{c}\Delta \mathrm{E}_{\mathrm{opt}}^{\mathrm{a}} \\
(\mathrm{eV})\end{array}$ & $\begin{array}{r}\Delta \mathrm{E}_{\mathrm{cV}}^{\mathrm{b}} \\
(\mathrm{eV})\end{array}$ & Transitions \\
\hline PP1 & -4.611 & -2.471 & $\begin{array}{l}437 \\
\text { (sh), } \\
526\end{array}$ & 2.36 & 1.94 & 1.75 & $\begin{array}{l}\text { HOMO->LUMO } \\
(100 \%)\end{array}$ \\
\hline PP2 & -4.450 & -2.542 & 591 & 2.09 & 1.70 & 1.44 & $\begin{array}{l}\text { HOMO->LUMO } \\
(100 \%)\end{array}$ \\
\hline \multirow[t]{2}{*}{ PP3 } & -4.636 & -2.432 & $\begin{array}{l}456 \\
525\end{array}$ & 2.36 & 2.00 & 1.86 & $\begin{array}{c}\text { HOMO->LUMO } \\
(91 \%)\end{array}$ \\
\hline & & & (sh) & & & & $\begin{array}{c}\text { HOMO- } \\
>\text { LUMO+1 (8\%) }\end{array}$ \\
\hline \multirow[t]{2}{*}{ PP4 } & -4.468 & -2.497 & $\begin{array}{l}497 \\
\text { (sh), }\end{array}$ & 2.15 & 1.74 & 1.52 & $\begin{array}{c}\text { HOMO->LUMO } \\
(95 \%)\end{array}$ \\
\hline & & & 577 & & & & $\begin{array}{c}\text { HOMO- } \\
>\text { LUMO+1 }(5 \%)\end{array}$ \\
\hline
\end{tabular}

a determined from the onset of the absorption band in the UV-visible

absorption spectrum. ${ }^{\mathrm{b}}$ determined by cyclic voltammetry

Table 2. Simulated absorption characteristics of PP1-PP4 in dichloromethane and comparison of the theoretical and experimental HOMO-LUMO gaps. 
Figure 5. Optimized geometries and contour plots of the HOMO and LUMO energy levels for the push-pull dyes PP1-PP4.

a)

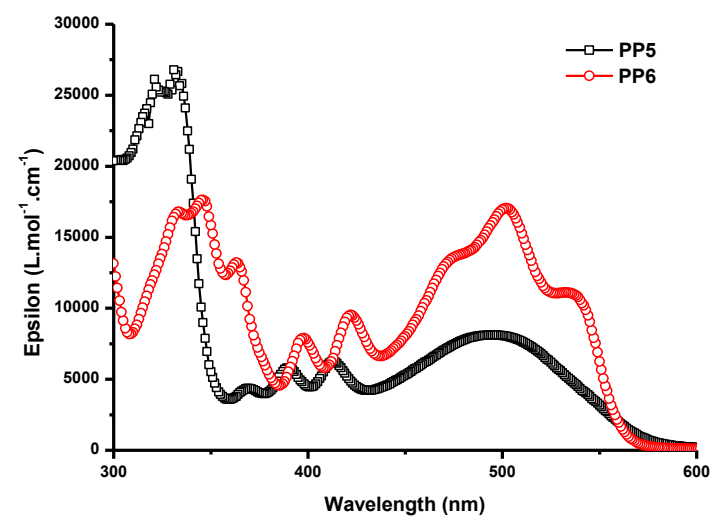

b)

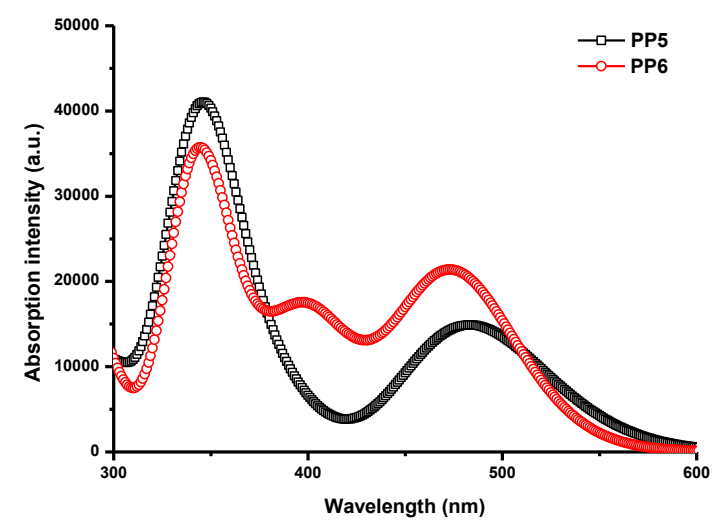

Figure 6. UV-visible absorption spectra of PP5 and PP6 in chloroform (a) and the theoretical UV-visible absorption spectra (b).

More complex UV-visible absorption spectra were found for PP5 and PP6 in chloroform solutions. As shown in the Figure 6, numerous transitions can be found in the visible range, at 413 and $496 \mathrm{~nm}$ for PP5, 420, 472, 502 and 537 nm for PP6 respectively. Theoretical calculations revealed these transitions to have numerous origins (see Table 3 and Figure 7). Besides the complexity of the transitions involved in the two spectra, a good accordance between the theoretical and the experimental spectra were found. Among the series of dyes investigated in this study, only PP5 and PP6 were photoluminescent and their emission spectra are presented in the Figure 8. The two spectra were obtained upon excitation of the molecules at $490 \mathrm{~nm}$ in chloroform. Despites the major difference of structures between PP5 and PP6, similar emission wavelengths were found for the two compounds. A maximum emission at 571 and 561 $\mathrm{nm}$ were respectively determined for PP5 and PP6.

Table 3. Simulated absorption characteristics of PP5 and PP6 in dilute dichloromethane.

\begin{tabular}{|c|c|c|c|c|}
\hline dyes & $\begin{array}{c}\text { Wavelength } \\
\text { (nm) }\end{array}$ & $\begin{array}{l}\text { Oscillator } \\
\text { Strength }\end{array}$ & $\begin{array}{c}\text { Major } \\
\text { contributions }\end{array}$ & $\begin{array}{c}\text { Minor } \\
\text { contributions }\end{array}$ \\
\hline \multirow[t]{5}{*}{ PP5 } & 505.97 & 0.0957 & HOMO->LUMO (95\%) & $\begin{array}{c}\text { HOMO-1->LUMO } \\
\text { (3\%) }\end{array}$ \\
\hline & 472.10 & 0.1543 & $\begin{array}{c}\text { HOMO-1->LUMO } \\
(94 \%)\end{array}$ & $\begin{array}{c}\text { HOMO->LUMO } \\
(4 \%)\end{array}$ \\
\hline & 387.22 & 0.0857 & $\begin{array}{c}\text { HOMO-2->LUMO } \\
(69 \%)\end{array}$ & $\begin{array}{c}\text { HOMO-3->LUMO } \\
(3 \%)\end{array}$ \\
\hline & & & $\begin{array}{c}\text { HOMO-1->LUMO+1 } \\
(11 \%)\end{array}$ & \\
\hline & & & $\begin{array}{c}\text { HOMO->LUMO+1 } \\
(12 \%)\end{array}$ & \\
\hline \multirow[t]{2}{*}{ PP6 } & 474.18 & 0.3133 & HOMO->LUMO (92\%) & $\begin{array}{c}\text { HOMO-2->LUMO } \\
(7 \%)\end{array}$ \\
\hline & 399.33 & 0.2441 & $\begin{array}{c}\text { HOMO- } 1 \text {->LUMO } \\
(88 \%)\end{array}$ & $\begin{array}{c}\text { HOMO->LUMO+1 } \\
(8 \%)\end{array}$ \\
\hline
\end{tabular}



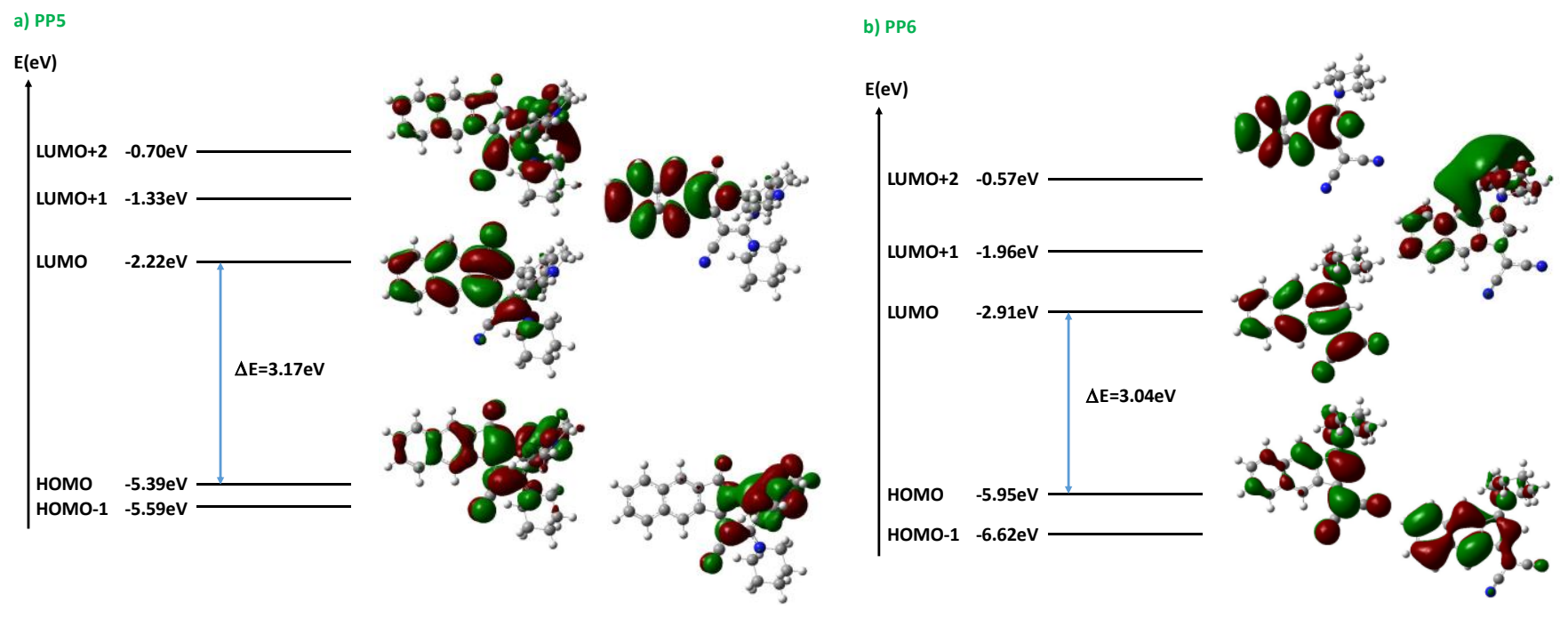

Figure 7. Optimized geometries and contour plots of the HOMO and LUMO energy levels for the push-pull dyes PP5, PP6. Energy diagrams for PP5 and PP6.

a)

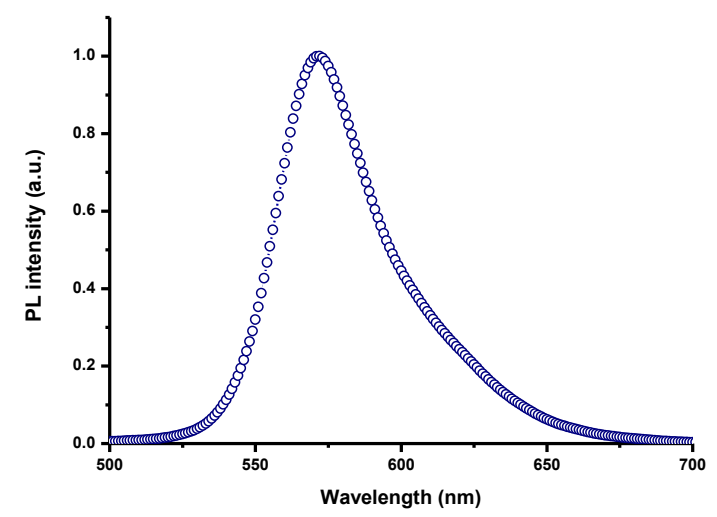

b)

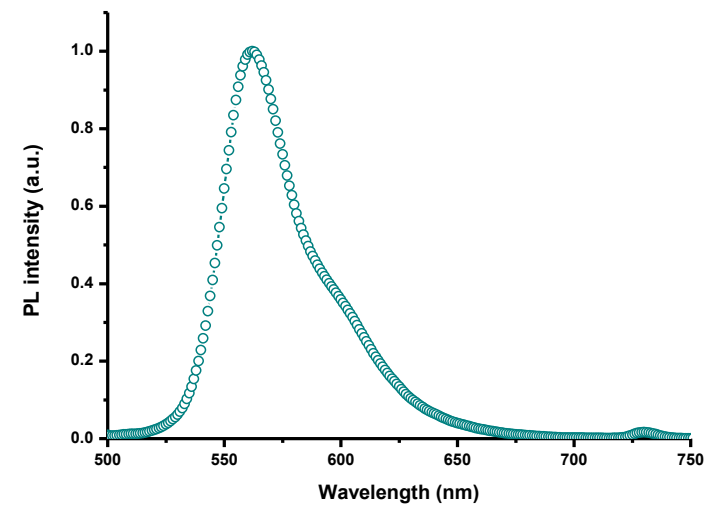

As mentioned in the introduction section, push-pull dyes can find applications in numerous research fields and their scope of applicability is greatly dominated by their electrochemical properties. Notably, in Organic Electronics, determination of the position of their respective $\mathrm{HOMO}$ and LUMO energy levels is of crucial importance to elaborate devices and select materials for the adjacent layers perfectly matching their energy levels. The electrochemical properties of PP1-PP6 were investigated by cyclic voltammetry, in dichloromethane. The redox potentials were calibrated against Ferrocene/Ferrocenium as the internal reference and a summary of the electrochemical properties are given in the Table 4. Figure 9 depicts the voltammograms of PP1, PP2 and PP3 in dichloromethane solutions containing tetrabutylammonium perchlorate as the supporting electrolyte. As shown in Figure 9a, PP1 and PP2 exhibited a reversible single-electron oxidation process and irreversible reduction peaks. Reduction of the oxidation potential for PP2 compared to PP1 is consistent with an easier oxidation process facilitated by the elongation of the electron donor.[28-31] Similarly, the monoelectronic reduction processes in PP1 and PP2 were affected by the elongation of the spacer. At similar electron acceptor, the reduction of $\mathbf{P P 2}$ was observed at a less cathodic potential by ca. $200 \mathrm{mV}$ compared to that of PP1. Thus, the irreversible reduction of PP2 was thus observed at $-1.16 \mathrm{~V}$ contrarily to $-1.26 \mathrm{~V}$ for PP1.

Figure 8. Fluorescence spectra of PP5 and PP6 in chloroform recorded upon photoexcitation at $490 \mathrm{~nm}$. 
a)

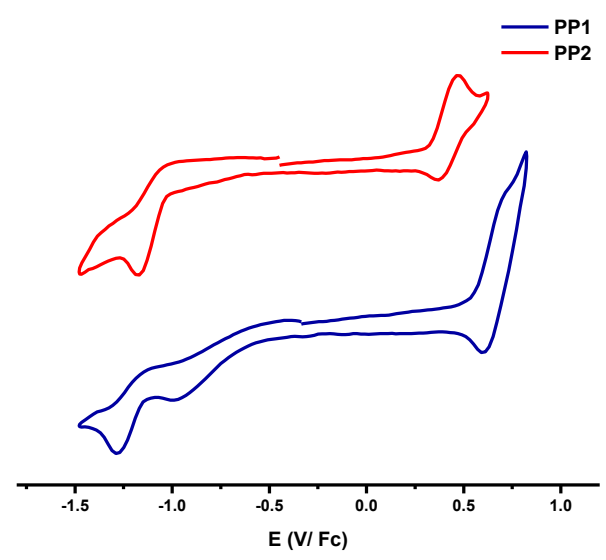

b)

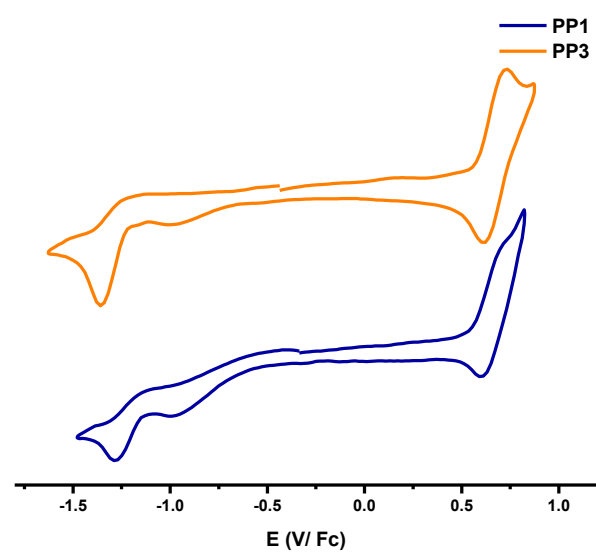

Figure 9. Cyclic voltammogram of PP1, PP2 and PP3 in dichloromethane solutions $\left(10^{-3} \mathrm{M}\right)$ with tetrabutylammonium perchlorate $(0.1 \mathrm{M})$ as the supporting electrolyte. Scan rate: $100 \mathrm{mV} / \mathrm{s}$

Table 4. Summary of the electrochemical properties of PP1-PP6.

\begin{tabular}{ccccccc}
\hline dyes & $\mathbf{E}_{\text {red }}{ }^{\mathrm{a}}$ & $\mathbf{E}_{\text {Red(Onset) }}{ }^{\mathrm{a}}$ & $\mathbf{E}_{\text {ox }}{ }^{\mathrm{a}, \mathrm{c}}$ & $\mathbf{E}_{\text {Ox(Onset) }}{ }^{\mathrm{a}, \mathrm{c}}$ & $\mathbf{E}_{\text {HOMO }}{ }^{\mathrm{b}}$ & $\mathbf{E}_{\text {LUMo }}{ }^{\mathrm{b}}$ \\
\hline PP1 & $-1.264^{\text {irr }}$ & -1.19 & 0.664 & 0.56 & -5.36 & -3.61 \\
PP2 & $-1.155^{\text {irr }}$ & -1.07 & 0.418 & 0.37 & -5.17 & -3.73 \\
PP3 & $-1.341^{\text {irr }}$ & -1.27 & 0.667 & 0.59 & -5.39 & -3.53 \\
PP4 & $-1.206^{\text {irr }}$ & -1.13 & 0.450 & 0.39 & -5.19 & -3.67 \\
PP5 & -1.409 & -1.15 & $0.323^{\text {irr }}$ & 0.23 & -5.03 & -3.65 \\
& & & $0.598^{\text {irr }}$ & 0.48 & & \\
PP6 & -1.482 & -1.43 & $0.832^{\text {irr }}$ & 0.72 & -5.52 & -3.37 \\
\hline
\end{tabular}

${ }^{a}$ All potentials are given in $\mathrm{V} .{ }^{\mathrm{b}} \mathrm{E}_{\text {Hомо }}$ and $\mathrm{E}_{\mathrm{LU}}$ ore given in $\mathrm{eV} .{ }^{\mathrm{c}}$ Onset oxidation and reduction potentials versus ferrocene ( $E_{\text {(onset) }}$ vs. $F c$ ). $E_{\text {HOMO }}$ and $E_{\text {LUMO }}$ were determined from the formulas : $E_{\text {Hомо }}=-4.8-E_{\text {ox(onset) }}$ vs. FC and $\mathrm{E}_{\text {LUMO }}=-4.8-\mathrm{E}_{\text {red(onset) }}$ Vs. FC

As evidenced in the Figure 5, the LUMO levels of PP1 and PP2 extend nonetheless over the electron-accepting part, but also on the whole molecule. As a result of this, Napht-EA is less acceptor in PP1 than in PP2 due to the closer proximity of the electron donating group, adversely affecting its electron-withdrawing ability. Generally, the opposite trend consisting in a cathodic shift of the reduction potential with elongation of the $\pi$-conjugated length is reported in the literature.[32] Remarkable examples of this were notably reported with strong electron acceptors such as poly(nitrofluorene).[33] However, in these different works, the LUMO level doesn't extend over the whole molecule, and HOMO and LUMO levels respectively centered onto the electron donor and the electron acceptor are observed. The situation differs for PP1 and PP2, for which the HOMO levels are localized onto the electron donor and the LUMO levels extend over the whole molecule. When a spacer is introduced, the distance isolates the electron acceptor from the donor so that a decrease of its reduction potential is observed.

While comparing PP1 and PP3 which differs by their electron acceptor (See Figure 9b), a decrease of the reduction potential by ca. $100 \mathrm{mV}$ could be observed for PP1 which comprises the most electron-withdrawing group. From the cyclic voltammograms and based on the oxidation and reduction potentials of PP1-PP4, an experimental determination of their HOMO and LUMO energy levels was possible.[34,35] As shown in the Figure 10 and in Table 4, a good agreement between the experimental and the theoretical values can be found. If a difference of $0.2 \mathrm{eV}$ and $0.4 \mathrm{eV}$ could be respectively found between the experimental and the theoretical values for the HOMO and the LUMO levels, variations of the theoretical HOMO and LUMO energy levels followed the same trend than that observed for the experimental ones.

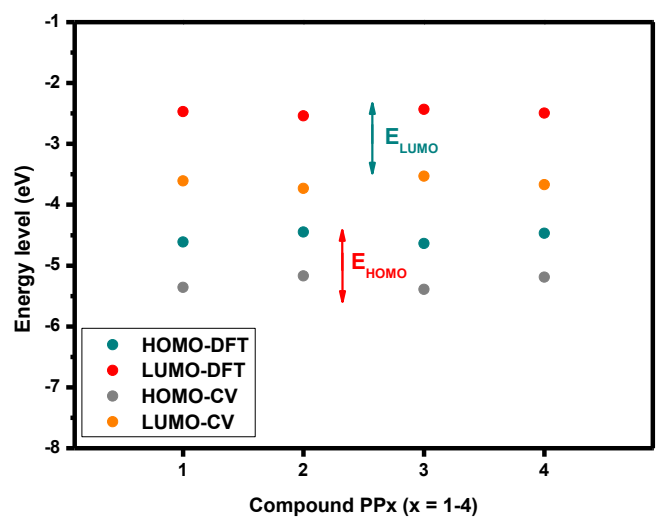

Figure 10. Comparison of the theoretical and experimental HOMO and LUMO energy levels for PP1-PP4.

Finally, the electrochemical properties of PP5 and PP6 were also examined. Only irreversible oxidation and reduction processes could be detected for PP5. Concerning the oxidation, two monoelectronic processes were detected at $0.82 \mathrm{~V}$ and $1.08 \mathrm{~V}$ whereas reduction 
processes were detected at $-0.49 \mathrm{~V}$ and $-0.92 \mathrm{~V}$ (See Figure 11a).

Conversely, for PP6, an irreversible oxidation process was detected at 0.82V, what is significantly higher than that observed for PP1-PP4.

This is consistent with an oxidation centered on the amine moiety, and the easier oxidation of the aromatic amines compared to the aliphatic ones. A reversible reduction process was also detected at 1.48V i.e. at a potential lower than that observed for PP1-PP4 (See Figure 11b).

a)

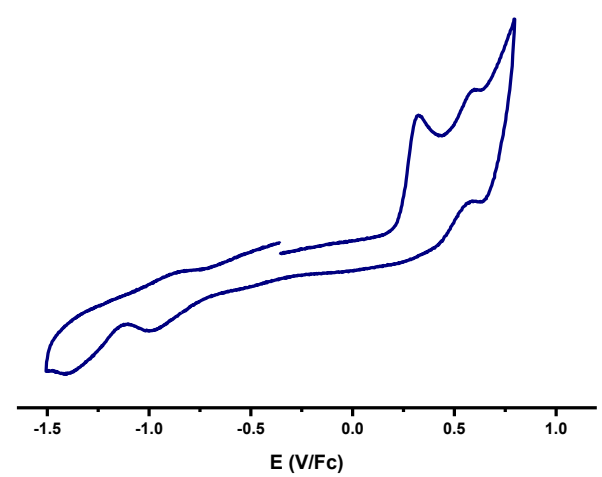

b)

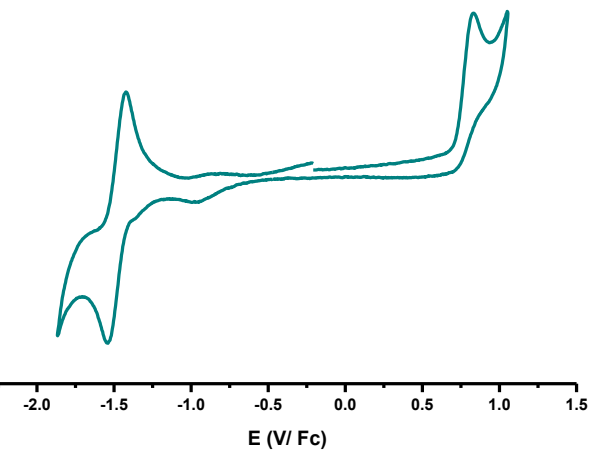

Figure 11. Cyclic voltammogram of PP5 (a) and PP6 (b) in dichloromethane solutions $\left(10^{-3} \mathrm{M}\right)$ with tetrabutylammonium perchlorate $(0.1 \mathrm{M})$ as the supporting electrolyte. Scan rate: $100 \mathrm{mV} / \mathrm{s}$.

\section{Conclusions}

To conclude, a series of push-pull dyes differing by their electron donating and electron-withdrawing groups have been designed and synthesized. Surprisingly, choice of the amine was determined as being crucial in order to prepare the different dyes PP1-PP4. While using the standard piperidine as a base for the Knoevenagel reaction, none of the targeted dyes PP1 and PP2 could be obtained but products (PP5 and PP6) resulting from the nucleophilic addition of piperidine on both the electron acceptor or the push-pull dye PP1 formed intermediately. This issue could be addressed by replacing piperidine by diisopropylethylamine. With regards to the optical and electrochemical properties of PP1 and PP2, Napht-EA is a remarkable electron acceptor for future developments of dyes with applications ranging from energy conversion to nonlinear optical applications. The development of new dyes is currently under progress and will be presented in forthcoming publications.

\section{Experimental Section}

\section{General informations}

All reagents and solvents were purchased from Aldrich, Alfa Aesar or $\mathrm{TCl}$ Europe and used as received without further purification. Mass spectroscopy was performed by the Spectropole of Aix-Marseille University. ESI mass spectral analyses were recorded with a 3200 QTRAP (Applied Biosystems SCIEX) mass spectrometer. The HRMS mass spectral analysis was performed with a QStar Elite (Applied Biosystems SCIEX) mass spectrometer. Elemental analyses were recorded with a Thermo Finnigan EA 1112 elemental analysis apparatus driven by the Eager 300 software. ${ }^{1} \mathrm{H}$ and ${ }^{13} \mathrm{C}$ NMR spectra were determined at room temperature in $5 \mathrm{~mm}$ o.d. tubes on a Bruker Avance 400 spectrometer of the Spectropole: ${ }^{1} \mathrm{H}(400 \mathrm{MHz})$ and ${ }^{13} \mathrm{C}(100 \mathrm{MHz})$. The ${ }^{1} \mathrm{H}$ chemical shifts were referenced to the solvent peak $\mathrm{CDCl}_{3}(7.26 \mathrm{ppm})$ and the ${ }^{13} \mathrm{C}$ chemical shifts were referenced to the solvent peak $\mathrm{CDCl}_{3}$ (77 ppm). 2-(3-Oxo-2,3dihydro-1H-inden-1-ylidene)malononitrile [36] and 3-(4-(dimethylamino)phenyl)acrylaldehyde [37] were synthesized as previously reported in the literature, without modification and in similar yields. UV-visible absorption spectra were recorded on a Varian Cary 50 Scan UV Visible Spectrophotometer, with concentration of $5 \times 10^{-3}$ $\mathrm{M}$, corresponding to diluted solutions. Fluorescence spectra were recorded using a Jasco FP 6200 spectrometer. The electrochemical properties of the investigated compounds were measured in dichloromethane by cyclic voltammetry, scan rate $100 \mathrm{mV} / \mathrm{s}$, with tetrabutylammonium perchlorate $(0.1 \mathrm{M})$ as a supporting electrolyte in a standard one-compartment, three-electrode electrochemical cell under an argon stream using a VSP BioLogic potentiostat. The working, pseudo-reference and counter electrodes were platinum disk $(\varnothing=1 \mathrm{~mm})$, Ag wire, and Au wire gauze, respectively. Ferrocene was used as an internal standard, and the potentials are referred to the reversible formal potential of this compound. DFT calculations [38] employing the B3LYP functionals $[39,40]$ and $6-311+G(d, p)$ basis set were performed with a Gaussian 09 program.[41] The geometry optimizations for all the molecules were carried out without symmetry constraints and were followed by frequency calculations. The spectroscopic properties of the molecules were calculated by mean of a time dependent density functional theory method 
(TDDFT).[42-46] Up to 10 excited states were calculated and the theoretical absorption bands were obtained by considering a band half-width at half-maximum of $0.2 \mathrm{eV}$.[47] The assignment of electronic transitions for $\lambda_{\max }$ has been determined with GaussSum 3.0 software.[48] CCDC-1907964 contains the supplementary crystallographic data for this work. These data can be obtained free of charge from The Cambridge Crystallographic Data Centre via www.ccdc.cam.ac.uk/data_request/cif.

Synthesis of the electron acceptors and push-pull dyes

2-(3-Oxo-2,3-dihydro-1H-cyclopenta[b]naphthalen-1-ylidene) malononitrile Napht-EA

In a dried two-necked $100 \mathrm{~mL}$ flask, $1 \mathrm{H}$-cyclopenta[b]naphthalene1,3(2H)-dione $(1.1 \mathrm{~g}, 5.6 \mathrm{mmol})$ and malononitrile $(2.2 \mathrm{~g}, 33.3 \mathrm{mmol})$ were dissolved in ethanol $(25 \mathrm{~mL})$, and then anhydrous sodium acetate $(1.84 \mathrm{~g}$ ) was slowly added while stirring. After stirring for $2 \mathrm{~h}$, the reaction mixture was poured into ice-water, and acidified to $\mathrm{pH}$ $1-2$ by the addition of concentred hydrochloric acid. The resulting precipitate was collected by filtration and washed with water giving the crude product. It was finally purified with a flash chromatography to afford $916 \mathrm{mg}$ of product (eluent : DCM). Yield $=67 \%$. ${ }^{1} \mathrm{H}$ NMR (400 MHz, CDCl $\left.)_{3}\right) \delta: 3.85(\mathrm{~s}, 2 \mathrm{H}), 7.79(\mathrm{dd}, 2 \mathrm{H}, \mathrm{J}=6.2 \mathrm{~Hz}, \mathrm{~J}=3.2 \mathrm{~Hz})$, 8.07-8.19 (m, 2H), $\left.8.49(\mathrm{~s}, 1 \mathrm{H}), 9.19(\mathrm{~s}, 1 \mathrm{H}) ;{ }^{13} \mathrm{C} \mathrm{NMR} \mathrm{(100} \mathrm{MHz,} \mathrm{CDCl}_{3}\right)$ $\delta: 44.6,112.3,112.6,125.8,128.1,130.5,130.6,130.7,130.9,135.8$, 136.3, 136.4, 166.5, 195.3; HRMS (ESI MS) m/z: theor: 244.0637 found: $244.0640\left([\mathrm{M}]^{+\cdot}\right.$ detected $)$

\section{$\underline{1 H \text {-Cyclopenta[b]naphthalene-1,3(2H)-dione }}$}

Diethyl naphthalene-2,3-dicarboxylate (10.5 g, $38.5 \mathrm{mmol})$ was suspended in dry EtOAc (24 mL) and $\mathrm{NaH} 95 \%$ in oil $(2.44 \mathrm{~g}, 96.4$ $\mathrm{mmol}, 2.5 \mathrm{eq}$ ) was added. The reaction mixture was refluxed at $105^{\circ} \mathrm{C}$ for $5 \mathrm{~h}$. After cooling, the yellow solid was filtered off and thoroughly washed with a mixture of EtOH-Et $2 \mathrm{O} 50 / 50$. Treatment of this solid with $200 \mathrm{~mL}$ of a $1 \mathrm{M} \mathrm{HCl}$ solution under reflux for $1 \mathrm{~h} 30$ furnished a new solid. After cooling, the solid was filtered off, washed with water and recrystallized in toluene $(200 \mathrm{~mL})$ overnight. The product was obtained as a brown solid (6.87 g). Yield =91\%. ${ }^{1} \mathrm{H}$ NMR $(400 \mathrm{MHz}$, $\left.\mathrm{CDCl}_{3}\right)$ \&: $3.38(\mathrm{~s}, 2 \mathrm{H}), 7.66-7.75(\mathrm{~m}, 2 \mathrm{H}), 8.10-8.13(\mathrm{~m}, 2 \mathrm{H}), 8.52(\mathrm{~s}$, $2 \mathrm{H}) ;{ }^{13} \mathrm{C}$ NMR $\left(100 \mathrm{MHz} \mathrm{CDCl}_{3}\right) \delta: 46.7,124.3,129.7,130.6,136.4$, 138.2, 197.6; HRMS (ESI MS) m/z: theor: 196.0524 found: 196.0526 $\left([\mathrm{M}]^{+} \cdot\right.$ detected $)$

General procedure for the synthesis of the push-pull dyes PP1-PP4

\section{2-(3-Oxo-2,3-dihydro-1H-cyclopenta[b]naphthalen-1-ylidene)} malononitrile

Napht-EA (0.62 g, 2.55 mmol) or 2-(3-oxo-2,3-dihydro-1H-inden-1ylidene)malononitrile $(0.50 \mathrm{~g}, 2.55 \mathrm{mmol})$ and the appropriate aldehyde (4-dimethylaminobenzaldehyde $(0.38 \mathrm{~g})$ or 3-(4-(dimethylamino)phenyl)acrylaldehyde (0.45 g, $2.55 \mathrm{mmol}$, 1. eq.) were dissolved in absolute ethanol $(50 \mathrm{~mL})$ and a few drops of DIPEA were added. The reaction mixture was refluxed and progress of the reaction was followed by thin layer chromatography (TLC). After cooling, a precipitate formed. It was filtered off, washed several times with ethanol and dried under vacuum.

\section{2-(2-(4-(Dimethylamino)benzylidene)-3-oxo-2,3-dihydro- $1 \mathrm{H}$ - cyclopenta $[b]$ naphthalen-1-ylidene)malononitrile PP1}

Yield $=68 \% .{ }^{1} \mathrm{H}$ NMR $\left(400 \mathrm{MHz} \mathrm{CDCl}_{3}\right) \delta: 3.23(\mathrm{~s}, 6 \mathrm{H}), 6.77(\mathrm{~d}, 2 \mathrm{H}, \mathrm{J}=$ $9.2 \mathrm{~Hz}), 7.65-7.67(\mathrm{~m}, 2 \mathrm{H}), 8.01-8.03(\mathrm{~m}, 1 \mathrm{H}), 8.06-8.08(\mathrm{~m}, 1 \mathrm{H}), 8.32$ $(\mathrm{s}, 1 \mathrm{H}), 8.44(\mathrm{~d}, 2 \mathrm{H}, \mathrm{J}=9.2 \mathrm{~Hz}), 8.57(\mathrm{~s}, 1 \mathrm{H}), 9.14(\mathrm{~s}, 1 \mathrm{H})$; HRMS (ESI MS) m/z: theor: 376.1444 found: $376.1442\left([\mathrm{M}+\mathrm{H}]^{+}\right.$detected); Anal. Calc. for $\mathrm{C}_{25} \mathrm{H}_{17} \mathrm{~N}_{3} \mathrm{O}$ : C, 80.0; $\mathrm{H}, 11.2 ; \mathrm{O}, 4.3$; Found: $\mathrm{C}, 79.8 ; \mathrm{H}, 11.3 ; \mathrm{O}$, $4.5 \%$

2-(-2-(-3-(4-(Dimethylamino)phenyl)allylidene)-3-oxo-2,3-dihydro$\underline{1 H \text {-cyclopenta }[b] \text { naphthalen-1-ylidene)malononitrile PP2 }}$

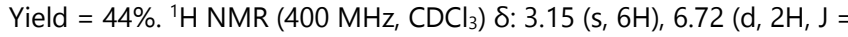
$9.0 \mathrm{~Hz}), 7.46(\mathrm{~d}, 1 \mathrm{H}, \mathrm{J}=14.8 \mathrm{~Hz}), 7.66-7.68(\mathrm{~m}, 3 \mathrm{H}), 8.02-8.08(\mathrm{~m}, 2 \mathrm{H})$, $8.32(\mathrm{~s}, 1 \mathrm{H}), 8.61(\mathrm{~d}, 1 \mathrm{H}, \mathrm{J}=11.9 \mathrm{~Hz}), 8.78(\mathrm{dd}, 1 \mathrm{H}, \mathrm{J}=12.0 \mathrm{~Hz}, \mathrm{~J}=$ 14.6 Hz), 9.15 (s, 1H) ; HRMS (ESI MS) m/z: theor: 402.1601 found: $402.1600\left([\mathrm{M}+\mathrm{H}]^{+}\right.$detected); Anal. Calc. for $\mathrm{C}_{27} \mathrm{H}_{19} \mathrm{~N}_{3} \mathrm{O}$ : C, 80.8; $\mathrm{H}, 4.8$; O, 4.0; Found: $\mathrm{C}, 80.6 ; \mathrm{H}, 4.6 ; \mathrm{O}, 4.1 \%$

2-(2-(4-(Dimethylamino)benzylidene)-3-oxo-2,3-dihydro- $1 \mathrm{H}$-inden-

1-ylidene)malononitrile PP3

Yield $=55 \% .{ }^{1} \mathrm{H}$ NMR $\left(400 \mathrm{MHz}_{1} \mathrm{CDCl}_{3}\right) \delta: 3.19(\mathrm{~s}, 6 \mathrm{H}), 6.74(\mathrm{~d}, 2 \mathrm{H}, \mathrm{J}=$ $9.2 \mathrm{~Hz}), 7.65-7.72(\mathrm{~m}, 2 \mathrm{H}), 7.84-7.86(\mathrm{~m}, 1 \mathrm{H}), 8.37(\mathrm{~d}, 2 \mathrm{H}, \mathrm{J}=9.2 \mathrm{~Hz})$, $8.62(\mathrm{~s}, 1 \mathrm{H}), 8.64(\mathrm{~d}, 1 \mathrm{H}, \mathrm{J}=8.0 \mathrm{~Hz}) ;{ }^{13} \mathrm{C} \mathrm{NMR}\left(100 \mathrm{MHz}, \mathrm{CDCl}_{3}\right) \delta$ : 40.2, 67.3, 111.5, 115.2, 115.4, 121.9, 122.6, 123.4, 124.7, 133.9, 134.4, 137.3, 139.1, 139.6, 148.2, 154.7, 163.5, 187.4; HRMS (ESI MS) m/z: theor: 326.3785 found: $326.3788\left([\mathrm{M}+\mathrm{H}]^{+}\right.$detected $)$.

2-(2-(3-(4-(Dimethylamino)phenyl)allylidene)-3-oxo-2,3-dihydro-1Hinden-1-ylidene)malononitrile PP4 [49]

Yield $=45 \% .{ }^{1} \mathrm{H}$ NMR $\left(400 \mathrm{MHz} \mathrm{CDCl}_{3}\right) \delta: 3.13(\mathrm{~s}, 6 \mathrm{H}), 6.70(\mathrm{~d}, 2 \mathrm{H}, \mathrm{J}=$ $8.9 \mathrm{~Hz}), 7.39(\mathrm{~d}, 1 \mathrm{H}, \mathrm{J}=14.7 \mathrm{~Hz}), 7.62(\mathrm{~d}, 2 \mathrm{H}, \mathrm{J}=8.9 \mathrm{~Hz}), 7.68-7.71(\mathrm{~m}$ $2 \mathrm{H}), 7.85-7.88(\mathrm{~m}, 1 \mathrm{H}), 8.51(\mathrm{~d}, 1 \mathrm{H}, \mathrm{J}=11.9 \mathrm{~Hz}), 8.61-8.70(\mathrm{~m}, 2 \mathrm{H}) ;{ }^{13} \mathrm{C}$ NMR (100 MHz, $\left.\mathrm{CDCl}_{3}\right)$ ס: 40.2, 67.3, 112.1, 115.1, 115.2, 120.1, 122.4, 
123.3, 123.9, 125.0, 132.5, 133.9, 134.5, 137.3, 139.9, 149.0, 153.3,

156.2, 160.3, 189.8; HRMS (ESI MS) m/z: theor: 352.1444 found:

$352.1441\left([\mathrm{M}+\mathrm{H}]^{+}\right.$detected $)$.

1-(4-(Dimethylamino)phenyl)-11-oxo-3-(piperidin-1-yl)-2,11dihydro- $1 \mathrm{H}$-benzo[5,6]indeno[2,1-c]pyridine-4-carbonitrile PP5 3-(4-(Dimethylamino)phenyl)acrylaldehyde (287 mg, 1,64 mmol, 1 eq.) and Napht-EA (400 mg, $1.64 \mathrm{mmol}, 1$ eq.) were introduced in a preheated solution of ethanol $(40 \mathrm{~mL})$. the selected amine $(0.5 \mathrm{~mL})$ was added in the former solution while boiling. Monitoring of the reaction was done by TLC and the solution was approximately refluxed for $30 \mathrm{~min}$. Depending of the amine, upon cooling, a precipitate formed in most of the time. This solid was filtered off and discarded. Addition of $\mathrm{Et}_{2} \mathrm{O}$ in the filtrate furnished a precipitate that was filtered off, washed with ether and dried under vacuum. Yield = 14\%. ${ }^{1} \mathrm{H}$ NMR (400 MHz, Acetone- $\left.\mathrm{d}_{6}\right) \delta: 1.68-1.80(\mathrm{~m}, 6 \mathrm{H}), 2.90(\mathrm{~s}$, $6 \mathrm{H}), 3.58-3.87(\mathrm{~m}, 4 \mathrm{H}), 5.59(\mathrm{~d}, 2 \mathrm{H}, \mathrm{J}=4.8 \mathrm{~Hz}), 6.71(\mathrm{~d}, 2 \mathrm{H}, \mathrm{J}=8.8 \mathrm{~Hz})$, $7.23(\mathrm{~d}, 2 \mathrm{H}, \mathrm{J}=8.8 \mathrm{~Hz}), 7.48-7.61(\mathrm{~m}, 2 \mathrm{H}), 7.74(\mathrm{~s}, 1 \mathrm{H}), 7.93(\mathrm{dd}, 2 \mathrm{H}, \mathrm{J}$ $=13.7 \mathrm{~Hz}, \mathrm{~J}=, 7.5 \mathrm{~Hz}), 8.20(\mathrm{~s}, 1 \mathrm{H}) ;{ }^{1} \mathrm{H}$ NMR $\left(400 \mathrm{MHz}, \mathrm{CDCl}_{3}\right) \delta$ : 1.72-1.75 (m, 6H), $2.90(\mathrm{~s}, 6 \mathrm{H}), 3.50-3.57(\mathrm{~m}, 2 \mathrm{H}), 3.62-3.68(\mathrm{~m}, 2 \mathrm{H})$, 5.57-5.60 (m, 2H), $6.67(\mathrm{~d}, 2 \mathrm{H}, \mathrm{J}=8.5 \mathrm{~Hz}), 7.25(\mathrm{~d}, 2 \mathrm{H}, \mathrm{J}=8.5 \mathrm{~Hz})$, 7.40-7.48 (m, 2H), $7.71(\mathrm{~s}, 1 \mathrm{H}), 7.77(\mathrm{~d}, 1 \mathrm{H}, \mathrm{J}=7.6 \mathrm{~Hz}), 7.82(\mathrm{~d}, 1 \mathrm{H}, \mathrm{J}=$ $7.6 \mathrm{~Hz}$ ), $8.18(\mathrm{~s}, 1 \mathrm{H})$; HRMS (ESI MS) m/z: theor: 461.2336 found: $461.2333\left([\mathrm{M}+\mathrm{H}]^{+}\right.$detected); Anal. Calc. for $\mathrm{C}_{30} \mathrm{H}_{28} \mathrm{~N}_{4} \mathrm{O}: \mathrm{C}, 78.3 ; \mathrm{H}, 6.1$; O, 3.5; Found: $\mathrm{C}, 78.6 ; \mathrm{H}, 6.2 ; \mathrm{O}, 3.3 \%$

\section{2-(3-(Piperidin-1-yl)-1H-cyclopenta[b]naphthalen-1-ylidene) malononitrile PP6}

4-Dimethylaminobenzaldehyde $(0.77 \mathrm{~g}, 5.15 \mathrm{mmol}$ ) and 2-(3-oxo2,3-dihydro-1H-cyclopenta[b]naphthalen-1-ylidene)malononitrile Napht-EA $(1.25 \mathrm{~g}, 5.15 \mathrm{mmol})$ were suspended in absolute ethanol $(20 \mathrm{~mL})$ and a few drops of piperidine were added. Immediately, the solution turned deep red. The flask was introduced in an oil bath preheated at $90^{\circ} \mathrm{C}$. After $15 \mathrm{~min}$, the reaction was ended (TLC control). During that time, an extremely insoluble precipitate was formed. After cooling, the precipitate was filtered off, washed several times with ethanol and ether, and dried under vacuum. Yield $=86 \%$; ${ }^{1} \mathrm{H}$ NMR (400 MHz, CDCl $)$ \&: 1.85 (brs, 6H), 3.86 (brs, 4H), 5.87 (s, 1H), 7.52-7.57 (m, 2H), 7.77-7.89 (m, 3H), $8.57(\mathrm{~s}, 1 \mathrm{H}) ;{ }^{13} \mathrm{C} \mathrm{NMR} \mathrm{(100} \mathrm{MHz,}$ $\left.\mathrm{CDCl}_{3}\right) \delta:{ }^{13} \mathrm{C}$ NMR $\left(75 \mathrm{MHz}_{1} \mathrm{CDCl}_{3}\right) \delta 23.8,26.1,51.5,56.9,103.1$, 116.9, 117.0, 123.7, 124.3, 128.40, 128.41, 129.5, 129.8, 133.1, 133.3, 133.5, 134.3, 161.8, 162.6; HRMS (ESI MS) m/z: theor: 312.1495 found: $312.1492\left([\mathrm{M}]^{+} \cdot\right.$ detected $)$

\section{Supplementary Material}

Supporting information for this article is available on the WWW under http://dx.doi.org/10.1002/MS-number. CCDC-1907964 contains the supplementary crystallographic data for this work. These data can be obtained free of charge from The Cambridge Crystallographic Data Centre via www.ccdc.cam.ac.uk/data_request/cif.

\section{Acknowledgements}

The authors thank Aix Marseille University and The Centre National de la Recherche (CNRS) for financial supports. The Agence Nationale de la Recherche (ANR agency) is acknowledged for its financial support through the PhD grants of Corentin Pigot (ANR-17-CE080010 DUALITY project) and Guillaume Noirbent (ANR-17-CE08-0054 VISICAT project). Said Aboudou is acknowledged as Master student from the Master Nanosciences and Nanotechnologies of Aix Marseille University for its contribution to the photophysical characterizations of the dyes.

\section{Author Contribution Statement}

C.P., G.N. and F.D. conceived this work. C.P. and F.D. designed and executed the experimental work, analyzed the data and discussed the results. C.P. and G.N. realized the chemical characterizations and the photophysical analysis of the compounds. S.D. solved the crystal structures. S.P. carried out the theoretical calculations. M.N. and D.G. did a critical review of the manuscript. C.P., G.N. and F.D. contributed to writing and editing the manuscript.

\section{References}

[1] A.S. Klymchenko, 'Solvatochromic and fluorogenic dyes as environmentsensitive probes: Design and biological applications', Acc. Chem. Res. 2017, 50, 366-375.

[2] X. Qian, Y. Xiao, Y. Xu, X. Guo, J. Qian, W. Zhu, "Alive" dyes as fluorescent sensors: fluorophore, mechanism, receptor and images in living cells', Chem. Commun. 2010, 46, 6418-6436.

[3] Y. Hu, W.A. Webre, M.B. Thomas, A. Moss, S.N. Hancock, J. Schaffner, F. D'Souza, H. Wang, ' $\beta$-Functionalized push-pull opp-dibenzoporphyrins as sensitizers for dye-sensitized solar cells: the role of the phenylethynyl bridge', J. Mater. Chem. A 2019, 7, 10712-10722.

[4] Q. Qi, R. Li, J. Luo, B. Zheng, K.-W. Huang, P. Wang, J. Wu, 'Push-pull type porphyrin-based sensitizers: The effect of donor structure on the lightharvesting ability and photovoltaic performance', Dyes Pigm. 2015, 122, 199-205.

[5] Y. Nicolas, F. Allama, M. Lepeltier, J. Massin, F. Castet, L. Ducasse, L. Hirsch, Z. Boubegtiten, G. Jonusauskas, C. Olivier, T. Toupance, 'New synthetic routes towards soluble and dissymmetric triphenodioxazine dyes designed for dye-sensitized solar cells', Chem. Eur. J. 2014, 20, 3678-3688. 
[6] P. Devibala, R. Dheepika, P. Vadivelu, S. Nagarajan, 'Synthesis of aroylbenzoate-based push-pull molecules for OFET applications', Chem. Select. 2019, 4, 2339-2346.

[7] S. Redon, G. Eucat, M. Ipuy, E. Jeanneau, I. Gautier-Luneau, A. Ibanez, C. Andraud, Y. Bretonnière, 'Tuning the solid-state emission of small pushpull dipolar dyes to the far-red through variation of the electron-acceptor group', Dyes Pigm. 2018, 156, 116-132.

[8] S. Forget, S. Chenais, D. Tondelier, B. Geffroy, I. Gozhyk, M. Lebental, E. Ishow, 'Red-emitting fluorescent organic light emitting diodes with low sensitivity to self-quenching', J. Appl. Phys. 2010, 108, 064509.

[9] N. Mohammed, A.A. Wiles, M. Belsley, S.S.M. Fernandes, M. Cariello, V.M Rotello, M.M.M. Raposo, G. Cooke, 'Synthesis and characterisation of push-pull flavin dyes with efficient second harmonic generation (SHG) properties', RSC Adv. 2017, 7, 24462-24469.

[10] G. Ulrich, A. Barsella, A. Boeglin, S. Niu, R. Ziessel, 'BODIPY - bridged push - pull chromophores for nonlinear optical applications', ChemPhysChem 2014, 15, 2693-2700.

[11] M.-A. Tehfe, F. Dumur, B. Graff, F. Morlet-Savary, D. Gigmes, J.-P. Fouassier J. Lalevée, 'Push-pull (thio)barbituric acid derivatives in dye photosensitized radical and cationic polymerization reactions under 457/473 nm Laser beams or blue LEDs', Polym. Chem. 2013, 4, 3866-3875.

[12] M.-A. Tehfe, F. Dumur, B. Graff, F. Morlet-Savary, D. Gigmes, J.-P. Fouassier, J. Lalevée, 'New push-pull dyes derived from Michler's ketone for polymerization reactions upon visible lights', Macromolecules 2013, 46, 3761-3770.

[13] H. Mokbel, S. Telitel, F. Dumur, L. Vidal, D.-L. Versace, M.-A. Tehfe, B. Graff, J. Toufaily, J.-P. Fouassier, D. Gigmes, T. Hamieh, J. Lalevée, 'Photoinitiating systems of polymerization and in-situ incorporation of metal nanoparticles in polymer matrixes upon visible lights: push-pull malonate and malonitrile based dyes', Polym. Chem. 2013, 4, 5679-5687.

[14] P. Xiao, M. Frigoli, F. Dumur, B. Graff, D. Gigmes, J.-P. Fouassier, J. Lalevée, 'Julolidine or fluorenone based push-pull dyes for polymerization upon soft polychromatic visible light or green light', Macromolecules 2014, 47, 106-112.

[15] M.-A. Tehfe, F. Dumur, B. Graff, D. Gigmes, J.-P. Fouassier, J. Lalevée, 'Blueto-red light sensitive push-pull structured photoinitiators: indanedione derivatives for radical and cationic photopolymerization reactions', Macromolecules 2013, 46, 3332-3341.

[16] G. Noirbent, F. Dumur, 'Recent advances on nitrofluorene derivatives: Versatile electron acceptors to create dyes absorbing from the visible to the near and far infrared region', Materials 2018, 11, 2425

[17] F. Bures, 'Fundamental aspects of property tuning in push-pull molecules', RSC Adv. 2014, 4, 58826-58851.

[18] E.V. Dalessandro, H.P. Collin, L.G.L. Guimarães, M.S. Valle, J.R. Pliego, 'Mechanism of the piperidine-catalyzed Knoevenagel condensation reaction in methanol: The role of iminium and enolate ions', J. Phys. Chem. B 2017, 121, 5300-5307.

[19] D. Šarlah, A. Juranovic, B. Kožar, L. Rejc, A. Golobic, A. Petri, 'Synthesis of naphthalene-based push-pull molecules with a heteroaromatic electron acceptor', Molecules 2016, 21, 267.
[20] E. Knoevenagel, 'Ueber eine darstellungsweise des benzylidenacetessigesters', Ber. Dtsch. Chem. Ges. 1896, 29, 172-174.

[21] S.M. Swick, W. Zhu, M. Matta, T.J. Aldrich, A. Harbuzaru, J.T. Lopez Navarrete, R. Ponce Ortiz, K.L. Kohlstedt, G.C. Schatz, A. Facchetti, F.S. Melkonyan, T.J. Marks, 'Closely packed, low reorganization energy $\pi$ extended post-fullerene acceptors for efficient polymer solar cells', Proc. Natl. Acad. Sci. USA 2018, 115, E8341-E8348.

[22] M. Chang, Y. Wang, Y.-Q.-Q. Yi, X. Ke, X. Wan, C. Li, Y. Chen, 'Fine-tuning the side-chains of non-fullerene small molecule acceptors to match with appropriate polymer donors', J. Mater. Chem. A 2018, 6, 8586-8594.

[23] H. Feng, N. Qiu, X. Wang, Y. Wang, B. Kan, X. Wan, M. Zhang, A. Xia, C. Li, F. Liu, H. Zhang, Y. Chen, 'An a-d-a type small-molecule electron acceptor with end-extended conjugation for high performance organic solar cells', Chem. Mater. 2017, 29, 7908-7917.

[24] D.R. Buckle, N.J. Morgan, J.W. Ross, H. Smith, B.A. Spicer, 'Antiallergic activity of 2-nitroindan-1, 3-diones', J. Med. Chem. 1973, 16, 1334-1339.

[25] T. Landmesser, A. Linden, H.-J. Hansen, 'A novel route to 1-substituted 3-(dialkylamino)-9-oxo-9H-indeno[2,1-c]-pyridine-4-carbonitriles', Helv. Chim. Acta 2008, 91, 265-284.

[26] A. Brzeczek, K. Piwowar, W. Domagala, M.M. Mikołajczyk, K. Walczak, P. Wagner, 'Systematic elongation of thienyl linkers and their effect on optical and electrochemical properties in carbazole-BODIPY donoracceptor systems', RSC Adv. 2016, 6, 36500-36509.

[27] Y. Lee, A. Jo, S.B. Park, 'Rational improvement of molar absorptivity guided by oscillator strength: $A$ case study with furoindolizine-based core skeleton', Angew. Chem. Int. Ed. 2015, 54, 15689-15693.

[28] C. Pigot, G. Noirbent, T.-T. Bui, S. Péralta, D. Gigmes, M. Nechab, F. Dumur, 'Push-pull chromophores based on the naphthalene scaffold: Potential candidates for optoelectronic applications', Materials 2019, 12, 1342.

[29] V. Malytskyi, V. Gadenne, Y. Ksari, L. Patrone, J.-M. Raimundo, 'Synthesis and characterization of thiophene-based push-pull chromophores for tuning the electrical and optical properties of surfaces with controlled SAM formation', Tetrahedron 2017, 73, 5738-5744.

[30] J.-M. Raimundo, P. Blanchard, N. Gallego-Planas, N. Mercier, I. LedouxRak, R. Hierle, J. Roncali, 'Design and synthesis of push-pull chromophores for second-order nonlinear optics derived from rigidified thiophenebased $\pi$-conjugating spacers', J. Org. Chem. 2002, 67, 205-218.

[31] A. Guerlin, F. Dumur, E. Dumas, F. Miomandre, G. Wantz, C.R. Mayer, 'Tunable optical properties of chromophores derived from oligo( $p$ phenylene vinylene)', Org. Lett. 2010, 12, 2382-2385.

[32] I.F. Perepichka, D.F. Perepichka M.R. Bryce, L.M. Goldenberg, L.G. Kuzmina, A.F. Popov, A. Chesney, A.J. Moore, J.A.K. Howard, N.I. Sokolov, 'Fluorene acceptors with intramolecular charge-transfer from 1,3-dithiole donor moieties: Novel electron transport materials', Chem. Commun. 1998, 819820.

[33] G. Noirbent, F. Dumur, 'Recent advances on nitrofluorene derivatives: Versatile electron acceptors to create dyes absorbing from the visible to the near and far infrared region', Materials, 2018, 11, 2425.

[34] F. Dumur, L. Beouch, S. Peralta, G. Wantz, F. Goubard, D. Gigmes, 'Solution-processed blue phosphorescent OLEDs with carbazole-based polymeric host materials', Org. Electron. 2015, 25, 21-30. 
[35] J. Pomrnerehne, H. Vestweber, W. Gun, R.E. Muhrt, H. Bassler, M. Porsch J. Daub, 'Efficient two-layer LEDs on a polymer blend basis', Adv. Mater. 1995, 7, 551-554

[36] Y. Cui, H. Ren, J. Yu, Z. Wang, G. Qian, 'An indanone-based alkoxysilane dye with second order nonlinear optical properties', Dyes Pigm. 2009, 81, 53-57.

[37] I. Malina, V. Kampars, B. Turovska, S. Belyakov, 'Novel green-yelloworange-red light emitting donor-p-acceptor type dyes based on 1,3indandione and dimedone moieties', Dyes Pigm. 2017, 139, 820-830.

[38] W. Kohn, L.J. Sham, 'Self-Consistent Equations Including Exchange and Correlation Effects', Phys. Rev. 1965, 140, A1133-A1138.

[39] C. Lee, W. Yang, R.G. Parr, 'Development of the Colle-Salvetti correlationenergy formula into a functional of the electron density', Phys. Rev. B: Condens. Matter Mater. Phys. 1988, 37, 785-789.

[40] A.D. Becke, 'Density - functional thermochemistry. III. The role of exact exchange', J. Chem. Phys. 1993, 98, 5648-5652.

[41] M.J. Frisch, G.W. Trucks, H.B. Schlegel, G.E. Scuseria, M.A. Robb, J.R. Cheeseman, G. Scalmani, V. Barone, G.A. Petersson, H. Nakatsuji, X. Li, M. Caricato, A. Marenich, J. Bloino, B.G. Janesko, R. Gomperts, B. Mennucci, H.P. Hratchian, J.V. Ortiz, A.F. Izmaylov, J.L. Sonnenberg, D. WilliamsYoung, F. Ding, F. Lipparini, F. Egidi, J. Goings, B. Peng, A. Petrone, T. Henderson, D. Ranasinghe, V.G. Zakrzewski, J. Gao, N. Rega, G. Zheng, W. Liang, M. Hada, M. Ehara, K. Toyota, R. Fukuda, J. Hasegawa, M. Ishida, T. Nakajima, Y. Honda, O. Kitao, H. Nakai, T. Vreven, K. Throssell, J.A. Montgomery, Jr., J.E. Peralta, F. Ogliaro, M. Bearpark, J.J. Heyd, E. Brothers, K.N. Kudin, V.N. Staroverov, T. Keith, R. Kobayashi, J. Normand, K. Raghavachari, A. Rendell, J.C. Burant, S.S. Iyengar, J. Tomasi, M. Cossi, J.M. Millam, M. Klene, C. Adamo, R. Cammi, J.W. Ochterski, R.L. Martin, K. Morokuma, O. Farkas, J.B. Foresman, and D.J. Fox, Gaussian, Inc., GAUSSIAN 09 (Revision B.01), Gaussian, Inc., Wallingford, CT, 2009.

[42] E. Gross, W. Kohn, 'Local density-functional theory of frequencydependent linear response', Phys. Rev. Lett. 1985, 55, 2850-2852.

[43] E. Runge, E.K.U. Gross, 'Density-functional theory for time-dependent systems', Phys. Rev. Lett. 1984, 52, 997-1000.

[44] E.K.U. Gross, W. Kohn, Density functional theory of many-fermion systems, Adv. Quant. Chem. 1990, 21, 1-405.

[45] R. Bauernschmitt, R. Ahlrichs, 'Treatment of electronic excitations within the adiabatic approximation of time dependent density functional theory' Chem. Phys. Lett. 1996, 256, 454-464.

[46] M.E. Casida, C. Jamorski, K.C. Casida, D.R. Salahub, 'Molecular excitation energies to high-lying bound states from time-dependent density functional response theory: Characterization and correction of the time dependent local density approximation ionization threshold', J. Chem. Phys. 1998, 108, 4439-4449.

[47] R. Dennington, T. Keith, J. Millam, GAUSSVIEW (Version 5), Semichem Inc., Shawnee Mission KS, 2009

[48] N.M. O'Boyle, A.L. Tenderholt, K.M. Langner. 'cclib: a library for packageindependent computational chemistry algorithms', J. Comp. Chem. 2008, $29,839-845$

[49] G. Meshulam, G. Berkovic, Z. Kotler, A. Ben-Asuly, R. Mazor, L. Shapiro, V. Khodorkovsky, '2-D effects in the second-order optical nonlinearity of organic molecules incorporating carbazole', Synth. Met. 2000, 115, 219223. 


\section{Entry for the Table of Contents}

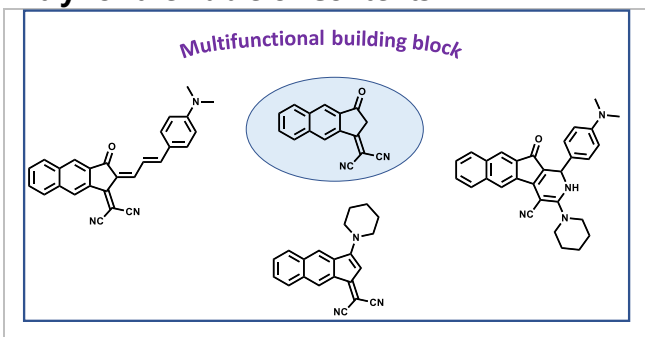




\section{Click here to access/download \\ Supporting Information \\ 2- Helvetica Chimica Acta revised version_supinf.docx}


Click here to access/download Additional Material - Author 0- Revised Letter HCA.doc 